\title{
Alppiruusulajikkeet ja niiden jalostus
}

\author{
Marjatta Uosukainen \\ MTT, Laukaan tutkimus- ja valiotaimiasema, Antinniementie 1, 41330 Vihtavuori, \\ marjatta.uosukainen@mtt.fi
}

\section{Johdanto}

Koristekasvien jalostus Suomessa kohdistuu ensisijaisesti talvenkestävyyteen, koska Suomi sijaitsee useiden lajien menestymisen äärirajoilla. Talvenkestävien alppiruusujen jalostusohjelma käynnistettiin Helsingin yliopiston Kasvinjalostustieteen laitoksella vuonna 1973. Alppiruusut valittiin jalostuksen kohteeksi, koska ainavihantien kasvien tarve suomalaisissa puutarhoissa ja puistoissa oli suuri. Ilmastollisesti riittävän kestävää kasviaineistoa ei kuitenkaan taimikaupassa ollut tarjolla. Etupäässä hollantilaisista taimistoista tuotiin 1970-luvun alussa vuosittain kymmeniä tuhansia taimia puistoalppiruusua ( $R$. catawbiense) ja risteymälajikkeita, jotka menestyivät tyydyttävästi vain Etelä-Suomen rannikkoalueella. Sisämaassa niiden menestyminen raja oli yleensä jo Salpausselän tienoilla.

Mustilan Arboretumiin 1900-luvun alkupuolella keskieurooppalaisista taimistoista ja jalostajilta hankitut aineistot sekä erityisesti Koreasta 1930-luvulla hankitut alppiruusulajit viihtyivät kuitenkin hyvin. Arboretumissa luonnon valinnassa jäljelle jääneet kasvit osoittivat, että suvun sadoissa lajeissa oli sellaista perintöaineistoa, josta oli löydettävissä myös Suomen ilmastoon sopivia yhdistelmiä. Mustilan alppiruusupuiston perustaja C. G. Tigerstedt ehdotti jo 1940-luvun pakkastalvien jälkeen, että Mustilan kestäviä alppiruusuja, eritoten Koreasta saatua Rhododendron brachycarpum-lajia tulisi käyttää jalostuksessa hyödyksi (Hagman \&Autio 1999).

Alppiruusut ovat monimuotoinen kasvisuku, jossa kukkien väri, kasvutapa, lehtimuodot ja talvenkestävyys vaihtelevat eri lajeissa ja niiden risteymissä lähes loputtomiin (Cox 1979, Cox 1990). Jalostusohjelmassa oli tavoitteena yhdistää talvenkestävyys ja koristeellisuus ja luoda Suomen puolimereiseen ilmastoon sopeutunut monimuotoinen alppiruusulajikkeisto. Keskeinen olettamus oli, että mustilanalppiruusun ja muiden arboretumissa hyvin menestyneiden alppiruusujen talvenkestävyys on periytettävissä risteytysjälkeläisiin, vaikka toisena vanhempana käytetään ilmastollisesti heikosti sopeutunutta, mutta muilta ominaisuuksiltaan kiinnostavaa genotyyppiä.

\section{Aineisto ja menetelmät}

Alppiruusujen jalostusohjelmassa käytettiin emokasveina Mustilan arboretumin kestävimpiä pensaita (Uosukai nen 1993). Tärkein emolaji oli vuonna 1930 Koreasta Suomeen saatu poikkeuksellisen talven-kestävä, mustilanalppiruusuna (R. brachycarpum ssp. tigerstedtii Nitz.) tunnettu laji (Nitzelius 1970). Muut keskeiset emolajit olivat nukka-alppiruusu ( $R$. smirnowii Trautv.) ja puistoalppiruusu ( $R$. catawbiense Michaux.) sekä niiden hybridit. Ruotsista, Tanskasta ja Hollannista tuotiin ilmastollisesti arempien, mutta koristeominaisuuksiltaan kiinnostavien lajien ja lajikkeiden siitepölyä (Uosukainen \& Tigerstedt 1988).

Jalostusohjelmassa tehtiin yhteensä 148 risteytysyhdistelmää vuosina 1973-1976. Kenttäkokeisiin eri puolille Suomea istutettiin 14000 risteytystainta. Koekenttiä antoivat käyttöön mm. Helsingin kau-punki,Mikkelin kaupunki, Maatalouden tutkimuskeskus Piikkiössä, Oulun yliopisto ja Kemira Oy:n Kot-kaniemen koetila (Uosukainen \& Tigerstedt 1988). Risteymätaimien talvehtimista, sopeutumista kasvuryt-miin, kevät-jasyyshar lan arkuutta, kasvutapaa, kukintaominaisuuksia ja pensaiden koristearvoa seurattiin 10-13 vuotta. Jalostusohjelman ohessa kehitettiin aineistolle taimikasvatus- ja mikrolisäysmenetelmät (Uosukainen 1976, Uosukainen \& Niskanen 1985). Aineistosta valittiin jatkotutkimuksiin n. 100 yksilöä, joista 70 mikrolisättiin kloonikokeisiin. Klooneja seurattiin 5-10 vuotta ennen lajikkeiden nimeämistä ja kaupallisen tuotannon aloittamista. Kloonien lisäysominaisuutta käytettiin yhtenä lajikkeiden valintaperusteena.

\section{Tulokset}

Risteyttäminen oli helppoa kukan suurten ja selkeiden osien takia, yhdestä pölytyksestä saatiin suuri määrä siemeniä, eikä lajien välisiä risteytymisesteitä juuri ilmennyt. Kenttäkokeiden perustaminen aloitettiin vuonna 1975. Aineisto altistui ankaralle karsinnalle vasta pakkastalvina 1984/1985 ja 1986/1987. Nämä poikkeuksellisen kylmät talvet testasivat jalostusaineiston pakkasenkestävyyden tehokkaasti, sillä niiden seurauksena aineistosta karsiutui pois keskimäärin 60 \% (Uosukainen \& Tigerstedt 1988). Näistä "pullonkaulavuosista" selvinneiden kasvien joukosta valittiin vuonna 1987 ensimmäiset 6 lajiketta, 'Elviira', 'Hellikki', 'Haaga', 'Helsinki University', 'P.M.A. Tigerstedt' ja 'St. Michel', jotka annettiin kaupalliseen lisäykseen (Uosukainen \& Tigerstedt 1988, Uosukainen 1989, Uosukainen 1999). Vuosituhannen vaihteeseen mennessä aineistosta oli valittu 9 lajiketta ja 
vuoden 2003 lopussa nimettyjä, tuotannossa olevia lajikkeita oli 12 (Taulukko1). Kovien pakkastalvien aiheuttamaa karsiutumista aineistoissa ei ole esiintynyt 1980-luvun jälkeen.

Jalostustyön tuloksena valikoitui lajikkeisto, joka voidaan kasvutapansa mukaan jakaa kolmeen ryhmään: 1) Kookkaat puistolajikkeet, 2) keskikorkeat puutarhalajikkeet ja 3) matalat lajikkeet. Kookkain lajike oli 'St. Michel', joka vanhemmiten kasvaa 2-3 m korkeaksi. Matalin toistaiseksi valituista lajikkeista oli lähes kääpiökasvuinen 'Elviira', joka täysikasvuisenakin on vain 0,5-0,75 m korkea. Kukkien yleisin värisävy jalostusaineistossa oli ruusunpunainen tai sitä vaaleampi. Paras punainen kukan väri oli kirsikanpunainen lajikkeella 'Elviira'. Voimakas punainen kukan väri oli myös lajikkeilla 'Raisa', 'Hellikki' ja 'Eino'. Ruusunpunaisia lajikkeita olivat 'Haaga' ja hiukan vaaleampi 'Helsinki University'. 'Pekka' oli selvästi vaaleanpunainen lajike. 'Pohjola's Daughter'-lajikkeen nuput ja nuoret kukat olivat violetin väriset ja vaalenivat kukinnan edetessä valkoisiksi. Lajikkeilla 'St. Michel', 'Kullervo' ja 'Axel Tigerstedt' nuput olivat vaaleanpunaiset, mutta täysin auenneet kukat olivat lähes valkoiset. Lajikkeen 'P.M.A. Tigerstedt' erikoisuus oli valkoisten kukkien ylälohkoissa oleva tumman purppuranpunainen täplitys. Lehdistön koristeellisuus vaikutti lajikkeiden 'St. Michel', 'Hellikki', 'Kullervo' ja 'Axel Tigerstedt' valintaan. Lajikkeiden vanhemmat on esitetty taulukossa 1.

Taulukko 1. Jalostusohjelmassa vuoden 2003 loppuun mennessä nimetyt ja kaupalliseen tuotantoon annetut lajikkeet, nimeämisvuodet (suluissa), lajikkeiden vanhemmat sekä kukan väri. Lajikkeet on ryhmitelty kookkaisiin, keskikorkeisiin ja mataliin.

\begin{tabular}{|c|c|c|}
\hline Lajike (vuosi) & Emokasvi x pölyttäjä & Kukan väri \\
\hline \multicolumn{3}{|l|}{ Kookkaat } \\
\hline 'St. Michel' (1987) & R. b. ssp. tigerstedtii $\mathrm{x}$ R. smirnowii & vaaleanpunainen \\
\hline 'Helsinki University' (1987) & R. $b$. ssp. tigerstedtii $\mathrm{x}$ tuntematon vapaapölytys & ruusunpunainen \\
\hline 'P.M.A. Tigerstedt' (1987) & R. b. ssp. tigerstedtii $\times$ R. catawbiense var. album 'Glass' & valkoinen \\
\hline 'Pekka' (1999) & $R . b$. ssp. tigerstedtii $\times$ R. Smirnowii-risteymä & vaaleanpunainen \\
\hline \multicolumn{3}{|l|}{ Keskikorkeat } \\
\hline 'Hellikki' (1987) & $R$. Smirnowii-risteymä $\mathrm{x}$ tuntematon vapaapölytys & $\begin{array}{l}\text { purppuranpunai- } \\
\text { nen }\end{array}$ \\
\hline 'Haaga' (1987) & R. $b$. ssp. tigerstedtii $\mathrm{x}$ R. 'Dr. H.C. Dresselhuys' & ruusunpunainen \\
\hline 'Axel Tigerstedt' (2002) & $R . b . \mathrm{ssp}$. tigerstedtii $\mathrm{x}$ R. degroniamum $\mathrm{ssp}$. degronianum & valkoinen \\
\hline 'Raisa' (2003) & $R . b$. ssp. tigerstedtii $\times$ R. Brachycarpum-risteymä & tummanpunainen \\
\hline 'Eino' (2003) & R. Smirnowii-risteymä $x R$. 'Dr. H.C. Dresselhuys' & $\begin{array}{l}\text { purppuranpunai- } \\
\text { nen }\end{array}$ \\
\hline \multicolumn{3}{|l|}{ Matalat } \\
\hline 'Elviiira' (1987) & $R . b . \mathrm{ssp}$. tigerstedtii $i \mathrm{x} R$. forrestii $\mathrm{ssp}$. forrestii & kirsikanpunainen \\
\hline 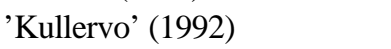 & R. b. ssp. tigerstedtii $\mathrm{x}$ R. degroniamum ssp. yakushimanum & vaaleanpunainen \\
\hline 'Pohjola's Daughter' (1996) & R. 'Cunningham's White' $x$ R. smirnowii & violetti-valkoinen \\
\hline
\end{tabular}

R. b. = Rhododendron brachycarpum

Lajikkeiden lopulliset valinnat tehtiin Maa- ja elintarviketalouden tutkimuskeskuksen (MTT) Laukaan tutkimus - ja valiotaimiasemalla kloonivertailussa saatujen tukosten perusteella. Kloonien menestymistä on seurattiin 5-10 vuotta. Vaikka 1980-luvun jälkeen ei ole esiintynyt poikkeuksellisen kylmiä pakkastalvia, on aineiston valinnassa jouduttu viime vuosina kiinnittämään huomiota kloonien kykyyn sietää kuivuutta. Useita vuosia jatkunut kuiva sääjakso ja pohjaveden alhaisuus on aiheuttanut suurilehtisille alppiruusuille talvehtimisvaurioita ja pensaiden harsuuntumista.

Suomalaisessa puutarhakasvien nimistössä suomalaisia mustilanalppiruusuihin pohjautuvia lajikkeita alettiin kutsua ryhmänimellä marjatanalppiruusut. Suurin osa valituista lajikkeista kuuluikin tähän ryhmään,koska toinen niiden vanhemmista oli mustilanalppiruusu. Nukka-alppiruusu oli mukana neljän lajikkeen perimässä ja puistoalppiruusun perimä oli mukana kolmessa lajikkeessa. Eri lajien osuudet lajikkeiden perimässä on esitetty kuvassa 1. Koska alppiruusujen jalostuksessa on käytetty perinteisesti myös vapaapölytteisiä siemenjälkeläi siä, oli tuntemattoman perimän osuus näissäkin lajikkeissa suuri. Mustilan arboretumin parhaiten menestyneistä alppiruusuista suuri osa oli saksalaisia Seidel-risteymiä (Uosukainen 1993), joissa tiettävästi oli käytetty vanhempina ainakin lajeja $R$. smirnowii ja $R$. arboreum. Kasvien ilmiasun perusteella voidaan olettaa, että osa tuntemattomasta geeniperimästä oli näistä lajeista, mutta lajien keskinäistä suhdetta ei tiedetä. Ilmiasun perusteella voidaan myös olettaa, että vapaapölytteisen lajikkeen 'Helsinki University' tuntematon isä olisi joku emopensaan lähistöllä kasvaneista puistoalppiruusun ( $R$. catawbiense) risteymälajikkeista. 
Kuva 1. Vuoden 2003 loppuun mennessä nimetyt 12 alppiruusulajiketta (X-akselilla) sekä risteytyksissä käytettyjen Rhododendron-lajien (selitteessä) osuus (\%) lajikkeen perimässä.

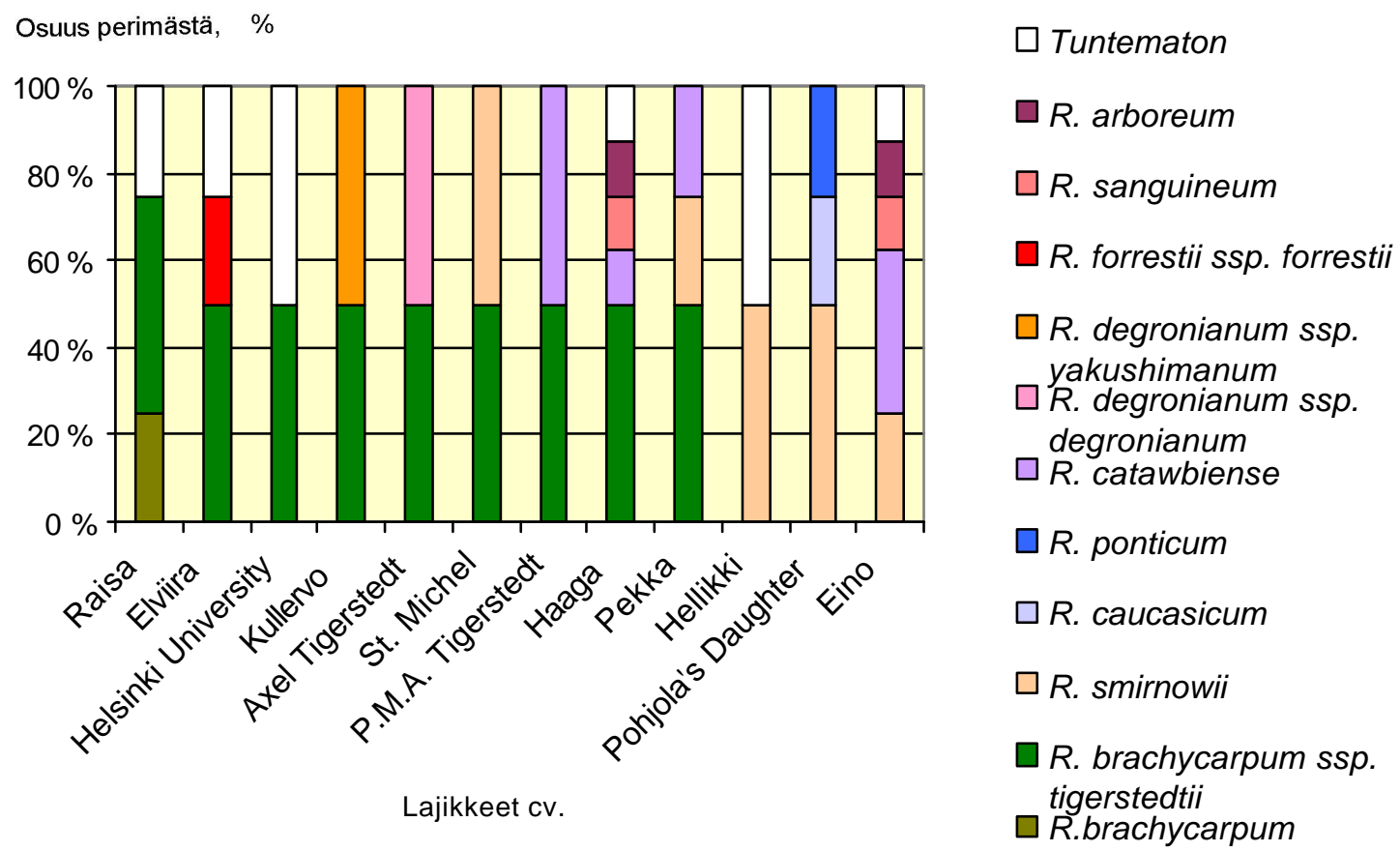

Talvenkestävyydeltään parhaat jälkeläispopulaatiot saatiin lajien välisistä risteytyksistä, joissa emokasvina oli mustilanalppiruusu ja pölyttäjänä oli käytetty joko nukka-alppiruusua tai nikonalppiruusua $(R$. degronianum ssp. degronianum, syn. $R$. metternichii) sekä puistoalppiruusuristeymästä, jossa pölyttäjänä oli mustilanalppiruusu (Uosukainen 1992). Koska näiden risteytysjälkeläisten kukkien värit olivat vaaleita, joko valkoisia, vaaleanpunaisia tai hennon ruusunpunaisia, jouduttiin lajikevalinnassa talvenkestävyys arvioimaan yksilötasolla ottaen samalla huomioon myös kukintaominaisuudet ja muut lajikkeiden koristearvoon vaikuttavat ominaisuudet. Jalostusaineistossa on edelleen mahdollista valita lajikkeita, jotka poikkeavat jo valituista lajikkeista ja täydentävät lajikevalikoimaa ryhmien sisällä. Matalien lajikkeiden ryhmään saadaan täydennystä piakkoin.

\section{Johtopäätökset}

Talvenkestävyysjalostus on suomalaisen kasvinjalostuksen vahvuus ja erityispiirre. $R$. brachycarpum ssp.tigerstedtii Nitz. tuli Suomeen siemenlähetyksenä Koreasta todennäköisesti vuoden 1931 alussa ja on siitä lähtien kestänyt kovimmatkin talvet. Keräyspaikan korkeus merenpinnasta oli $1200 \mathrm{~m}$. Laji on sopeutunut ilmastoon, jossa absoluuttinen minimilämpötila on $-35,4^{\circ} \mathrm{C}$ ja vuotuinen keskimääräinen sademäärä on $566 \mathrm{~mm}$. (Hagman \& Autio 1999). Nämä olosuhteet ovat hyvin samankaltaiset kuin Suomessa, jossa vuotuinen sademäärä Etelä-ja Keski-Suomessa on $600-750 \mathrm{~mm} / \mathrm{v}$ ja keskimääräinen $-35,4^{\circ} \mathrm{C}$ absoluuttisen minimilämpötilan raja kulkee karkeasti linjalla Ylitorniosta Joensuuhun (Alalammi 1987).

Olettamus mustilanalppiruusun käyttökelpoisuudesta jalostusohjelman perustana oli perusteltua. Tulosten mukaan mustilanalppiruusun vaikutus risteymäjälkeläisten menestymiseen oli selvä. Jalostus-ohjelman seurauksena alppiruusujen menestymisalueen raja siirtyi Suomessa pohjoisemmaksi. Myös Pohjois-Amerikassa suomalaisten lajikkeiden avulla alppiruusujen viljelyalue on laajentunut mantereen kylmillä alueilla. Kestävimpien uusien lajikkeiden menestymisalue vastaa mustilanalppiruusun ilmastollista kestävyysaluetta.

Mustilanalppiruusun heikkoudeksi todettiin Mustilassa voimakas sopeutuneisuus mantereiseen ilmastoon ja sen seurauksena alttius keväthalloille (Uosukainen 1992). Uusissa lajikkeissa tämä heikkous korjaantui, kun mustilanalppiruusun perimä yhdistettiin mereisten ilmastojen lajeihin, kuten esimerkiksi $R$. smirnowii, $R$. catawbiense ja $R$. degronianum. Jalostusohjelman tulokset muiden kestävinä pidettyinä lajien, kuten nukkaalppiruusu ja puistoalppiruusu pakkasenkestävyydestä ovat myös vahvistaneet Coxin (1979) esittämän arvion, että mustilanalppiruusu on maailman kestävin alppiruusu.

Mantereista kasvutyyppiä edustava mustilanalppiruusu oli hyvä perusta alppiruusunjalostukselle.Or lakseen talvenkestäviä pohjoisilla ilmastovyöhykkeillä, kasvien tulee olla sopeutuneita lyhyeen kasvu-kauteen ja 
alhaiseen kasvukauden aikaiseen lämpösummakertymään. Niiden on oltava herkkiä syyskesän lyhenevän päivän ja lämpötilan alenemisen antamille viesteille, jotta talvituleentuminen käynnistyisi oikeaan aikaan. Kasvien on lisäksi kestettävä sydäntalven kylmimmät pakkaset myös pullonkaulavuosina sekä pysyttävä karaistuneina siihen asti, kunnes kasvukausi alkaa toukokuussa. Nämä ominaisuudet siirtyivät hyvin mustilanalppiruusun jälkeläisiin. Vaikka laji oli kookaskasvuinen ja lähes puumainen, sen jälkeläisten kasvutapaominaisuudet määräytyvät useimmiten pölyttäjälajikkeen ominaisuuksien mukaan. Tästä esimerkkeinä olivat mm. lajikkeet 'Elviira' ja 'Kullervo'. Alppiruusunjalostuksessa kukan värin periytyminen on usein ongelmallista. Parhaimmillaan värin periytyminen on keskiverto vanhempien väristä, joten kukkien värit jäävät melko vaaleiksi, jos toinen emoista on vaaleakukkainen. Tämäkin ominaisuus periytyi odotettua paremmin mustilanalppiruusun jälkeläisiin, mikäli pölyttäjälajike oli voimakasvärinen.

Jalostusohjelma onnistui, koska suuri yleisö selvästi tunsi kiinnostusta alppiruusuihin. Työn tuloksena oli uusien lajikkeiden lisäksi malli suomalaiselle koristekasvijalostukselle. Lisäksi syntyi uusi erikoistuotannon haara suomalaiseen taimituotantoon sekä uusi vientiartikkeli mm. Pohjois-Amerikan ja Pohjoismaiden markkinoille. Tulevaisuudessa taimia vietäneen myös Venäjälle ja muualle Itä-Eurooppaan. Suomalaiset alppiruusulajikkeet ovat hyvä perusta kestävien alppiruusulajikkeiden jalostuksessa myös maailmanlaajuisesti. PohjoisAmerikassa niitä on jo alettukin hyödyntää tässä tarkoituksessa.

\section{Kirjallisuus}

Alalammi, P. 1988. Suomen Kartasto. Ilmasto. (5. painos) Maanmittaushallitus ja Suomen maantieteellinen seura. 1987: 131. Maanmittaushallituksen Karttapaino. Helsinki. 32 p. ISBN 951-47-0970-5.

Hagman, M. \& Autio, A. 1999. Mustilanalppiruusun tarina (The story of the Tigerstedtii rhododendron). Sorbifolia 30 : 25-30.

Cox, P.A. 1979. The larger species of Rhododendron. B.T. Batsford Ltd. Lontoo. 352 s. ISBN 0-7134-1747-1.

Cox, P.A. 1990. The smaller Rhododendrons. B.T. Batsford Ltd. Lontoo. 271 s. ISBN 0-7134-4471-1.

Nitzelius, T.G. 1970. Rhododendron brachycarpum D.Don ex Don ssp. tigerstedtii eine neue Unterart. Vorläufige Mitteilung. Deitsche Baumschule 22(7): 207-212.

Uosukainen, M. 1976. Alppiruusun (Rhododendron sp.) siemenlisäys ja taimikasvatus. Dendrologian Seuran Tiedotuksia 7: 44-50.

Uosukainen, M. 1989. New iron-hardy Finnish Rhododendron cultivars. Teoksessa: Modern methods in the breeding and multiplication of ornamentals. (Vorträge und Zuzammenfassungen der Poster anlässlich der 15 Tagung der Sektion Zierpflanzen der EUCARPIA vom 5. bis 9. September 1988 in Erfurt.) Akademie der Landwirtschaftswissenschaften DDR, Tagungsbericht 281: 85-89. (ISSN-0138-2659.

Uosukainen, M. 1992. Rhododendron brachycarpum ssp. tigerstedtii Nitz. - A transmitter of extreme frosthardiness. Selection and breeding woody ornamentals . Acta Horticulturae 320: 77-83.

Uosukainen, M. 1993. Arboretum Mustila - a gene bank for Rhododendron breeding. Teoksessa: Mustila Arboretum as a centre for introducing and breeding shrubs and trees. Proceedings of the $90^{\text {th }}$ Anniversary Jubilee Symposium of Mustila Arboretum, Moisio Manor, 19-21 August 1992. Yliopistopaino. Helsinki. s. 70-80. ISBN 952-90-5015-1.

Uosukainen, M. 1999. Ensimmäiset suomalaiset alppiruusulajikkeet. (The first Finnish rhododendron cultivars). Sorbifolia 30: 17-24.

Uosukainen, M. \& Niskanen A.-M. 1985. Meristem tip culture of woody perennials. Hereditas, Supplementary volume 3: 153-154.

Uosukainen, M. \& Tigerstedt P.M.A. 1988. Breeding of frosthardy rhododendrons - Talvenkestävien alppiruusujen jalostus. Journal of Agricultural Science in Finland 60: 235-254. 